\title{
Unmonitored students self-created WhatsApp groups in distance learning environments: A collaborative learning tool or cheating technique
}

\author{
Alghamdi, Emad A. $\bowtie$ \\ King Abdulaziz University, Saudi Arabia (eaalghamdi@kau.edu.sa) \\ Rajab, Hussam \\ King Abdulaziz University, Saudi Arabia (hmrajab@kau.edu.sa)
}

Rashid Shah, Sayyed

King Abdulaziz University, Saudi Arabia (shakespeare.hamlet@yahoo.co.uk)

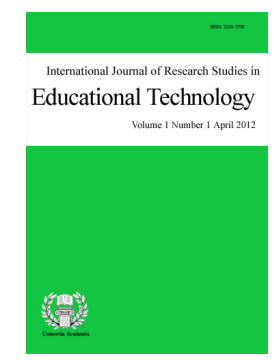

ISSN: $2243-7738$ Online ISSN: 2243-7746

OPEN ACCESS

\begin{abstract}
Recent advances of communication technology have brought a myriad of advantages to distance education. Students' interactivity and connectedness are no longer a concern in distance education. Yet, with this comes the challenge of maintaining academic integrity. As online instructors, we noticed a tendency among our online students to opt out of using our courses' formal discussion groups for their course communication, and instead, independently create a group in the social instant messaging app, WhatsApp, away from our direct observation. In this mixed method research, we first investigated what motivate our students $(n=64)$ to create the WhatsApp group and what types of interaction they engage in as a group. Then, we examined our online students' perceptions of cheating in reference to their participations in the group. Our findings revealed that our online students perceived cheating differently and expressed their objection to the inclusion of the term 'cheating' in the distance-learning contexts, as they believed that distance learning is an open educational environment which permits collaboration and open discussion.
\end{abstract}

Keywords: distance education; academic dishonesty; cheating; collaborative learning; WhatsApp; student discussions 


\section{Unmonitored students self-created WhatsApp groups in distance learning environments: A collaborative learning tool or cheating technique}

\section{Introduction}

In the grand scheme of things, the unprecedented advances and ubiquity of communication technologies have brought a myriad of pedagogical opportunities to distance and online education. Communication tools, for example, online forums, discussion groups, and social communication sites and apps, help in connecting students with their peers and with their instructor. Research into effective online teaching has accentuated the importance of building collaborative learning online communities wherein students are actively engaged (Dixson, 2010; Espasa \& Meneses, 2010). Online students need to feel they are belonging to a larger learning community. Cross (1998) defined learning communities as "groups of people engaged in intellectual interaction for the purpose of learning” (p. 4). Indeed, students' interactivity in online courses is a major determinant of students' good performance, satisfaction and persistence in online courses (Chejlyk, 2006; Keeler, 2006; Kuo, Walker, Schroder, \& Belland, 2014). In online courses, interactivity can occur between student-student, student-instructor and student-content. In his interaction equivalency theorem, Anderson (2003) asserted that meaningful learning could be achieved when at least one form of interactions is present at a high level, and the presence of more than one form of interactions lead to an even better and more satisfying educational experience.

As online instructors, we noticed a tendency among our students to create a group in the social instant messaging app WhatsApp on their own, removed from our direct observation and involvement, and opting not to use our courses' formal channel of communication, discussion forums, for their communication. Discussion forums allow students to communicate and discuss course related topics with fellow students and the instructor. In these forums, the instructor can monitor, facilitate and give feedback on his/her students' learning. Instructor's feedback is important and found to be associated with higher levels of students' engagement, stratification and performance in online courses (Espasa \& Meneses, 2010). Student-instructor communication is one of the greatest predictors of student satisfaction (Croxton, 2014). A convincing line of research underscores the benefits of an instructor's social presence on students' learning performance and engagement in online courses (Dixcon, 2010; Gayton \& McEwen, 2007; Thurmond, Wambach, Connors, and Frey, 2002; Young, 2006).

However, in our case, we were not involved in our students' private discussion group and we wondered if our students use this communication tool to collaboratively learn or cheat. It is believed that students in the present generation seem to hold a more fluid notion of what is considered unethical than students in the past (Gulli, 2007; Gulli, Kohler, \& Patriquin, 2007; Malesic, 2006; Troop, 2007). Howe and Straus (2003) believe that students of the millennial generation cannot distinguish between traditional concepts of cheating and the modern concepts of information 'morphing' (p. 120), and accordingly, they encounter "a difficulty recognizing traditional operational definitions of academic dishonesty” (Raines et al, 2011, p. 81).

With the use of communication tools, e.g., WhatsApp, has become the means for every day's communications for many people, untangling what online students perceive as cheating when using these technologies is of great importance for understanding and combating academic dishonesty in the socio-cultural context in which it occurs. Thus, the present study first investigates what motivates online Saudi students to create a group in WhatsApp and what types of interaction they engage in with this group. Then, it explores online students' understating of academic dishonesty in reference to their interaction and the information they share in the group that they created. The primary focus of this research is on academic integrity and as such we, in what follows, will review the relevant literature on the subject. 


\section{Literature Review}

Distance and online education is more susceptible to academic dishonesty. Students of the millennial generation are more comfortable and competent at using computers and new communication technology than their teachers, thus leaving teachers at odds on how to combat their students' innovative and circumventive cheating methods. In the past few years, cheating and academic dishonesty that involves the use of advanced technologies are replacing the simply "cut and paste" old cheating method (Jones, 2011). In a recent large-scale cheating incident in India, 600,000 Indian students were ordered by the Supreme Court to retake an exam after being caught cheating. Among many technology-based cheating techniques they used, students wore a "cheater's vest", a normal looking vest that conceals a tiny microphone connected to a cell phone receiver and an invisible Bluetooth earpiece, to receive unauthorized help from a more educated person off campus (Rowlatt, 2015).

Academic dishonesty is a generic term that encompasses a myriad of misconduct behaviours, for example, copying other students' answers during academic exams, failing to cite resources, or fabricating data. These types of behaviour are conceptually overlapping. Pavela (1997) classified academic dishonesty into four categories. (1) Cheating - intentionally using or attempting to use unauthorized materials, information, or study aids in any academic exercise; (2) Fabrication - Intentional and unauthorized falsification or invention of any information or citation in an academic exercise; (3) Facilitating Academic Dishonesty - intentionally or knowingly helping or attempting to help another to violate any provision of this Code and (4) Plagiarism intentionally or knowingly representing the words or ideas of another as one's own in any academic exercise. Students' use of technology to access and obtain authorized information is a form of cheating and is often referred to as e-cheating or cyber-cheating.

The plethora of research in academic dishonesty has been devoted to traditional education (e.g., McCabe, 1999; McCabe, Trevino, \& Butterfield, 2001; Michaels \& Miethe, 1989; Whitley, 1998; Hosny \& Fatima, 2014) and little research has examined academic dishonesty in distance and online education (Duran \& Fraser, 2012; Watson \& Sottile, 2010). Cheating is a global phenomenon and it is pervasive across diverse cultures (Magnus et al, 2002). Students from different parts of the world view cheating differently, cheat or plagiarize in different ways, and with different frequencies, and for various reasons (Eret \& Ok, 2014).

\subsection{The Prevalence of Cheating in Online Education}

Many studies have examined the prevalence of students' academic misconduct in online education in comparison to traditional education. The results, by and large, were inconclusive. Some researchers believe that cheating is more prevalent in online education than it is in traditional bricks and mortar education (Kennedy et al., 2000; King, Guette, \& Piotrowski, 2009). Cheating in online education is far more complex and online students use multiple methods to violate and degrade the integrity of the online courses. In McCabe's 2010 Academic Integrity Survey Report for Texas Tech University, more than 50\% of faculty members had observed students' misconduct during an online exam; more than $40 \%$ had observed students using notes or books on an online test or exam; and more than 35\% reported that students had received unpermitted help on an online test or exam or used the Internet to look up information (Texas Tech University, 2010). Adopting McCabe's survey, Jones, Blankenship and Hollier (2013) examined the perceptions of 194 online students regarding cheating in online courses. The findings revealed that $68.6 \%$ students indicated that they, at least once, used an open book during an online exam and $63.4 \%$ students indicated they used personal or class notes during an online exam.

Other studies, however, have downplayed the enormity of academic dishonesty in online education. For example, Grijalva, Nowell, and Kerkvliet (2006), based on an empirical investigation, reported that academic dishonesty in online education is not more prevalent than it is in traditional education. Similar findings are reported by Stuber-McEwen, Wisley and Hoggatt (2009). Watson and Sottile (2010) also found that cheating in online courses is less rampant than it is in traditional courses. They attributed this to the social interactions that develop among students in live classes, which help students to know each other and become friends, and lessen 
Alghamdi, E. A., Rajab, H., \& Rashid Shah, S.

their moral objections to cheating.

\subsection{Common Methods of Cheating in Online Education}

Methods and techniques of cheating in online classes are more complex and different from those of traditional classes. The use of low or high technological techniques and devices to unethically obtain, pass, or fabricate information is very common in online education. Students may use their phones to send and receive answers for an exam or use the Internet to look up information, while they are taking online exams (read Faucher, Rn, \& Caves, (2009) for more techniques used by students to cheat in online exams). Delinquency and unauthorized assistance are very common in online education (Hughes \& McCabe, 2006; Akbulut, Şendağ, Birinci, Kılıçer, Şahin, \& Odabaşı, 2008). Students may seek unauthorized help from other students, work on individual assignments with fellow students, or get answers from students who have already taken the test before.

\subsection{Students' Reasons for Cheating in Online Education}

Several reasons can explain why students cheat or plagiarize in their online academic endeavour. For example, students cheat or plagiarize because the claim the assignments are difficult or overwhelming; they had insufficient time to complete assignments; they desire to compete with fellow students and get better grades; or they feel incompetent in the subject matter (Duran \& Fraser, 2012; Rowe, 2004). Moreover, the remoteness or the physical disconnect between teachers and students can be a contributing factor to academic dishonesty in online education, triggering the tendency for cheating among those students who intend to cheat. When course demands escalate, students under pressure may give up on their ethical and moral judgments and beliefs. In their study, Hosny and Fatima (2014) found that cheating and plagiarism was rampant among Saudi female students despite many of them believing that it was unethical and against their religious values. Overall, cheating is perceived differently in different cultures. The current research study explores Saudi online students' perceptions of cheating in their interaction and communication in WhatsApp. Specifically, the present study aims to answer the following research questions:

$>\quad$ What motivates online students to create a discussion group in WhatsApp?

$>\quad$ What types of interaction do online students engage in with the WhatsApp group?

$>\quad$ What online students' beliefs and attitudes as to whether their WhatsApp group interactions constitute academic dishonesty?

\section{Methodology}

This study followed a convergent parallel interactive mixed method design (Creswell \& Clark, 2011) where both quantitative and qualitative data were collected concurrently via an online survey hosted by 'Google docs', and the web link to the survey was sent to 100 students. In total, 64 respondents completed the survey and 36 students either did not attempt or complete the survey, or partially completed it and thus were discarded. The survey had twenty-three items wherein twenty items had multi-Likert scale responses providing quantitative data, and three items were open-ended questions, which provided the qualitative data. The rationale behind utilising the mixed methods methodology in this research study is due to the fact that it is more convenient to have the pool of both quantitative and qualitative data in a single entity, which makes it very easy to compare and corroborate different data collected. Additionally, it is extremely difficult to collect data in various phases with distance learning students, since many of those students live in far and different parts of the Kingdom of Saudi Arabia. In addition, the majority of those students have busy life schedules, both at work and at home and thus, may not be able to participate in an interview. On the other hand, even with the few who may participate, it will take a very long time to arrange the interviews, collect data and analyse it. 


\subsection{Participants}

The participants were adult online Saudi students who were randomly selected from three different online preparatory year program classes. Due to the nature of cultural restrictions in Saudi Arabia where co-education is not permitted, the participants were all males ranging in age from 20 - 46 years old, and with different academic performances, as shown in Table 1.

Table 1

Participants' Age and GPA

\begin{tabular}{ccccccc}
\hline & \multicolumn{2}{c}{ Age } & & \multicolumn{3}{c}{ GPA } \\
\cline { 1 - 3 } \cline { 5 - 6 } Items & Freq. & $\%$ & & Items & Freq. & $\%$ \\
\hline $\mathbf{2 0}-\mathbf{2 5}$ & 19 & $29.7 \%$ & 1.99 & 6 & $9.4 \%$ \\
$\mathbf{2 6}-\mathbf{3 0}$ & 24 & $37.5 \%$ & & $2-2.99$ & 20 & $31.3 \%$ \\
$\mathbf{3 1 - 3 5}$ & 10 & $15.6 \%$ & & $3-3.99$ & 23 & $35.9 \%$ \\
$\mathbf{3 6 - 4 5}$ & 10 & $15.6 \%$ & & $4-5$ & 15 & $23.4 \%$ \\
$\mathbf{4 6 +}$ & 1 & $1.6 \%$ & & & \\
\hline
\end{tabular}

Concerning the reason for choosing to study online, the responses of the participants were mainly about attaining a bachelor degree, as shown in table 2.

\section{Table 2}

Why did you decide to study online?

\begin{tabular}{lcccc}
\hline & Frequency & Percent & Valid Percent & Cumulative Percent \\
\hline Earning a bachelor degree & 49 & 76.6 & 76.6 & 76.6 \\
Getting job promotions & 11 & 17.2 & 17.2 & 93.8 \\
Continuing my education & 1 & 1.6 & 1.6 & 95.3 \\
Gaining knowledge & 2 & 3.1 & 3.1 & 98.4 \\
All of the above & 1 & 1.6 & 1.6 & 100.0 \\
\hline
\end{tabular}

\subsection{Data Analysis Procedures}

As previously mentioned, data collection was carried out via an online survey hosted by Google docs and the data gathered was automatically recorded and saved on a password-protected drive, which only the researchers had access to. The ease with which data was collected meant that data analysis could begin immediately. Once the deadline of one week had passed, this analysis was performed using IBM SPSS Statistics $22^{\circledR}$ and NVivo $10^{\circledR}$, software. The initial language of the survey was in Arabic due to the English proficiency level of the students (elementary level) and thus, data collected was initially in Arabic and later translated into English.

The very first stage of the data analysis was to format the tables of the gathered Likert scale data using both Microsoft Excel ${ }^{\circledR}$ as well as IBM SPSS Statistics $22^{\circledR}$. Since IBM SPSS Statistics $22^{\circledR}$ analyse data in numerical format, responses were converted into reflective numbers corresponding to the Likert scale responses, in order to make the data more accessible and the analyses more comprehensible. As previously mentioned, the data was initially collected in Arabic. Since the researchers were fluent in both Arabic and English, the initial analysis on the data was performed in Arabic. Later on in the second phase, the data was translated into English, analysed and matched to that in Arabic, which were both identical and inferences drawn were exactly similar to each other. The first step taken in the data analysis was to test the internal consistency or reliability of the twenty Likert-scale items in the survey. This was carried out using the Cronbach's alpha test on the reflective assigned to each response. The calculated value of the Cronbach's alpha of 0.783 indicated that the survey is consistent 
Alghamdi, E. A., Rajab, H., \& Rashid Shah, S.

and reliable to be utilised for collecting data from the participants. Additionally, this relatively high value of the Cronbach's alpha indicated a high level of internal consistency for our Likert-scale survey questions and therefore, could be distributed confidently to the participants.

\section{Results}

\subsection{Quantitative Data Analysis}

The survey questions and statements were divided into three categories. The first category related to the demographic data. In this category, the participants were asked about their work status and age. The majority of the participants (94\%) indicated that they were working and 6\% indicated that they were not. Additionally, the ages of the participants varied where $30 \%$ indicated that they were between $20-25$ years old, $38 \%$ indicated that they were between $26-30$ years old, $15 \%$ indicated that they were between the $31-35$ years old, $15 \%$ indicated that they were between $36-45$ years old and $2 \%$ indicated that they were above 46 years old.

The second category in the survey related to participation in the social media WhatsApp software. When asked if they were members of a WhatsApp group, the majority $82.8 \%$ responded with a "yes". This was followed by a question about the type of participation they had in the group and the main reason why they joined the WhatsApp group. The majority of the participants (69\%) indicated that they joined in order to network and make new friends, exchange important information relating to new topics or special updates about a particular topic with them, and thus save time. A few of the participants (16\%) indicated that they joined the WhatsApp group so that they could remind each other of important dates (e.g. exam dates) as well as a change in timings of particular lectures (if any). Nonetheless, a few of the participants (15\%) indicated that they did not join or desire to join the WhatsApp group.

\section{Table 3}

What types of participation do you make in the group?

\begin{tabular}{lcccc}
\hline & Frequency & Percent & Valid Percent & Cumulative Percent \\
\hline Share my answers with my classmates & 14 & 21.9 & 21.9 & 21.9 \\
alert my classmates & 16 & 25.0 & 25.0 & 46.9 \\
General discussions & 20 & 31.3 & 31.3 & 78.1 \\
Ask questions & 6 & 9.4 & 9.4 & 87.5 \\
All of the above & 4 & 6.3 & 6.3 & 93.8 \\
Did not participate & 4 & 6.3 & 6.3 & 100.0 \\
\hline
\end{tabular}

The third category, which formed the bulk of the survey, related to the actual issue of academic dishonesty (or cheating). When the participants were asked about the perceptions of cheating being widespread in DL, the majority responded with "neither agree nor disagree" (30\%) as shown in table 4.

\section{Table 4}

Do you think cheating is widespread among distance learning students?

\begin{tabular}{lcc}
\hline & Frequency & Percent \\
\hline Strongly Agree & 12 & 19 \\
Agree & 12 & 19 \\
Neither Agree nor Disagree & 19 & 30 \\
Disagree & 9 & 13 \\
Strongly Disagree & 12 & 19 \\
\hline
\end{tabular}


In the subsequent series of questions relating to this category (cheating), the participants were asked if they considered sharing information with another student as a form of cheating. The majority (nearly 65\%) considered it a form of cheating and 35\% did not. In subsequent questions, the participants were asked to highlight their opinions with regards to several issues relating to their perception of helping colleagues, asking for help from colleagues and whether they perceived any of those activities as a form of cheating or not. Table 5 highlights the responses of the participants about the statements in this category (the third category).

\section{Table 5}

The third category questions in the survey (cheating category)

\begin{tabular}{|c|c|c|c|c|c|c|c|c|}
\hline \multirow[t]{2}{*}{ Question } & \multicolumn{2}{|c|}{ Always } & \multicolumn{2}{|c|}{$\begin{array}{c}\text { Almost Every } \\
\text { Time }\end{array}$} & \multicolumn{2}{|c|}{ Sometimes } & \multicolumn{2}{|c|}{ Never } \\
\hline & Count & $\%$ & Count & $\%$ & Count & $\%$ & Count & $\%$ \\
\hline $\begin{array}{l}\text { If you are faced with } \\
\text { difficulties understanding the } \\
\text { topics, do you ask someone to } \\
\text { help you? }\end{array}$ & 6 & $9 \%$ & 16 & $25 \%$ & 30 & $47 \%$ & 12 & $19 \%$ \\
\hline $\begin{array}{l}\text { If you are faced with } \\
\text { difficulties understanding the } \\
\text { topics, do you ask your } \\
\text { classmates for help? }\end{array}$ & 11 & $17 \%$ & 11 & $17 \%$ & 26 & $41 \%$ & 16 & $25 \%$ \\
\hline $\begin{array}{l}\text { Do you discuss your answers } \\
\text { with your classmates while } \\
\text { doing the homework? }\end{array}$ & 13 & $20 \%$ & 4 & $6 \%$ & 21 & $33 \%$ & 26 & $41 \%$ \\
\hline $\begin{array}{l}\text { Do you discuss your answers } \\
\text { with your classmates AFTER } \\
\text { you finish the homework? }\end{array}$ & 9 & $14 \%$ & 8 & $13 \%$ & 24 & $38 \%$ & 23 & $36 \%$ \\
\hline $\begin{array}{l}\text { If any of your classmates } \\
\text { asked for help with homework } \\
\text { and tasks, would you offer it } \\
\text { to him? }\end{array}$ & 25 & $39 \%$ & 3 & $5 \%$ & 19 & $30 \%$ & 17 & $27 \%$ \\
\hline
\end{tabular}

As can be seen from the above table, when the participants were asked if they had difficulties understanding a particular topic in the course, whether they would ask someone or their classmates for help or not, the majority of the respondents indicated that they would ask for help from someone (81\%) or from their classmates $(75 \%)$. When the participants were asked if they would discuss their homework answers with their classmates while doing the homework or after completing it, $41 \%$ responded with 'never' for sharing their answers while working on the homework, and $36 \%$ also responded with 'never' for sharing the answers after completing the homework. When the participants were asked if their classmates asked for help, whether they would offer help to them, nearly $74 \%$ responded with 'yes' and $27 \%$ responded with 'never'.

When the participants were asked to give their opinions and preferences on working alone or working in a group, the majority (67\%) expressed their preference towards working in a group rather than individually. The final question with Likert-scale responses related to whether the participants believed that working in a group was better than working alone. Their responses were to 'agree and strongly agree' (66.4\%) compared to disagree and strongly disagree $(33.6 \%)$.

\subsection{Qualitative Data Analysis}

There were three open-ended questions in the survey, which related to the perception of cheating as the participants saw it. The first question asked whether sharing information was considered cheating. In the second 
Alghamdi, E. A., Rajab, H., \& Rashid Shah, S.

question, the respondents had to state why they considered it to be cheating or not. The final question focused on the reasons why the respondents joined the WhatsApp group (if they had joined). The first step in the analysis of the gathered data of these three open-ended questions was to save all the data separately and using NVivo $10 \circledR$ software, analysis began by coding the text and looking at particular words or phrases' frequency in the text. For the first question relating to the definition of cheating as the participants perceived it, students seemed to have a solid foundation on what constitutes cheating (in principle). The majority of responses centred around "stealing" someone else's efforts, which is ethically unacceptable in academia, as well as leading to a harmful effect on society, where false representation of credentials means employing unfit or inefficient workers. Nearly $60 \%$ of the participants ascribed their definition and perception of cheating to the Islamic religious values of avoiding cheating and dishonesty in all aspects of life. Furthermore, it is evident that the students appreciate honesty and hard work in gaining knowledge and grades they rightly deserve, when they do not resort to cheating.

With regards to why the participants considered sharing answers and activities with colleagues a form of cheating (or not), most of the responses from the participants indicated that this is a type of peer and group work rather than a form of cheating. Several responses seemed to differentiate between certain types of communication relating to academic work outside the classroom or exam halls, and that, which exists away from any academic settings or environments and in the students' own time. A few vital responses indicated that distance learning is different to onsite learning in many aspects and thus, any form of communication in a distance-learning context, where it occurs outside the academic setting is not considered cheating, but rather a form of knowledge sharing and group work.

With regards to why the participants joined the WhatsApp group, a representative tag cloud was generated, as shown in figure 1.

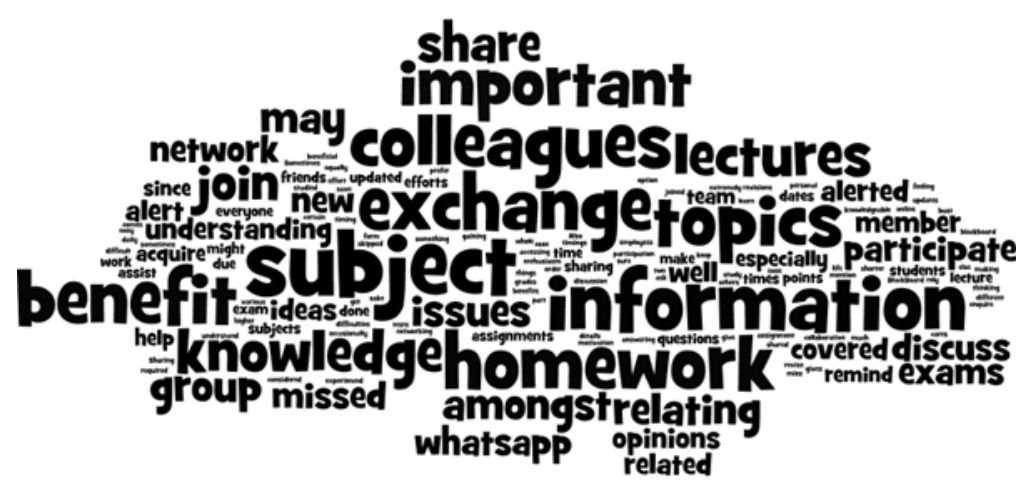

Figure 1. Tag cloud representing why the participants joined the WhatsApp group

Following the initial coding inquiry, the various initial codes generated were combined into emerging themes and eventually those emerging themes were given three labels, which were 'awareness' of what cheating is, 'morality' of issues that are related to cheating, and finally, 'divergence' between true cheating and collaboration in education. The majority of the responses of the participants on why they joined the WhatsApp group reflected positively on having the opportunity to network their work as a team, giving advanced notice on important dates and deadlines, helping each other understand a particular topic, and more importantly, the ease with which all these issues can be accomplished via the WhatsApp group. A few of the participants (19\%) responded with "I did not join the WhatsApp group".

\section{Discussion and Conclusion}

The issue of cheating and academic dishonesty in education has long been debated. In this study, an attempt was made to explore the concept of cheating from the students' own viewpoints and what perceptions and beliefs they hold in this regard in the Saudi distance-learning context. From the analysis of the data gathered in the survey, it is evident that the students expressed strong opinions when it came to questions relating to what they 
perceived as cheating, as well as strong opinions in differentiating and making clear distinctions between cheating and 'group discussions' or 'help' among colleagues. Some went the extra mile to express total objection to the inclusion of the term 'cheating' in the distance-learning context (barring the final exam for instance in an exam hall). They perceived distance learning to be an open educational environment, which permits collaboration, open discussion of various elements of the study and above all, encourages and promotes virtual collaboration and teamwork among colleagues and classmates. Previous studies (e.g., Robinson \& Kuin, 1999) indicated that students from collectivistic cultures, e.g., China and India, perceive working and collaborating in groups differently to students from Western countries, e.g., USA and UK. According to Hofstede's cultural dimensions theory, the Saudi Arabian society falls into the category of collectivistic societies where people place high value on group loyalty, collaboration and helping each other ("The Hofsteda Centre", 2015).

One particular outcome of the participants' responses indicated that it is sometimes the responsibility of educational institutions to clarify clearly, what they consider as cheating, in contrast to the recommended and approved students' group discussions and collaborations. Educational institutions policies should first determine what constitutes academic dishonesty or cheating in distance learning environments, especially concerning students' group collaborations and discussions that occur outside classrooms, away from the instructors' eyes, and then make sure that online students are familiar with and abide by these regulations. Given that academic dishonesty is context-specific, the institutional policies should be crafted in accordance with the socio-cultural contexts in which academic dishonesty occurs (Gullifer \& Tyson, 2013).

However, making students aware of university policy about academic dishonesty may be not sufficient to combat students' cheating. Gullifer and Tyson (2013) emphasize that, "universities must take a more proactive role, using a wide range of strategies" (p. 1215) and recommend taking an educative approch by offering students formal workshops to educate students about academic dishonesty, as opposed to relying merely on the expectation that students may read the policy and abide by it. Online instructors should warn their students of the consequences and the severity of punishment for academic misconduct. McCabe and Pavela (2004) pointed out that:

Students observe how faculty members behave and what values they embrace. Faculty members who ignore or trivialize academic dishonesty send the message that the core values of academic life aren't worth enforcing. Students then run the risk of developing harmful habits that can lead to far more serious consequences later (p. 15).

It is incumbent on distance learning instructors to set the boundaries between what are acceptable learning activities and what are not, and clearly communicate the penalties of cheating on a course syllabus. Online students seem to have a distorted notion of what constitutes cheating in online education and they usually confuse teamwork and collaborative work with individual learning activities (Raines et al., 2011).

\section{Limitations and Directions for Feature Reserch}

There are some limitations in this study. First, the primairy foucs of this study was on online students' perceptions and attitudes of cheating with reference to their interactions in the social group they created. As such, other cheating methods were not explored. Moreover, we used a self-report method to collect our primary data. A self-report questionnaire is a quick, practical, efficient and inexpensive method to solicit information on the subject under investigation, but it suffers from some serious deficits, on top of which is credibility and accuracy of information obtained via self-reports (Paulhus \& Vazire, 2007). Future studies should do a text-based analysis of online students' interactions in self-created discussion groups to accurately reveal what types of communication that students engage in via these groups. Moreover, there is a need for further studies that look into the issue from pedagogical perspectives. Social instant messaging apps, such as WhatsApp, are used by many students for their daily social communications and could be beneficial when carefuly integrated into online teaching practices. 
Acknowledgment: The authors would like to thank all the EFL faculty and students who participated and/or helped in conducting this research study. A special thanks to the Research Unit at the English Language Institute at King Abdulaziz University for approving the research study as well as various suggestions regarding certain elements in the research methodology.

\section{References}

Anderson, T. (2003). Getting the mix right again: An updated and theoretical rationale for interaction. The International Review of Research in Open and Distance Learning, 4(2). Retrieved from http://www.irrodl.org/index.php/irrodl/article/view/149/230

Akbulut, Y., Şendağ, S., Birinci, G., Kılıçer, K., Şahin, M., \& Odabaşı, H. (2008). Exploring the types and reasons of Internet-triggered academic dishonesty among Turkish undergraduate students: Development of Internet-triggered Academic Dishonesty Scale (ITADS). Computers and Education, 51(1), 463-473. http://dx.doi.org/10.1016/j.compedu.2007.06.003

Chejlyk, S. (2006). The effects of online course format and three components of student perceived interactions on overall course satisfaction (Doctoral dissertation). Available from ProQuest Dissertations \& Theses database. (UMI No. 3213421)

Creswell, J., \& Clark, V. (2011). Designing and Conducting Mixed Methods Research, SAGE Publications.

Croxton, R. A. (2014). The role of interactivity in student satisfaction and persistence in online learning. Merlot Journal of Online Learning and Teaching, 10(2), 314-325.

Dixson, .M. (2010).Creating effective student engagement in online courses: What do students find engaging? Journal of the Scholarship of Teaching and Learning, 10(2), 1-13.

Duran, M., \& Fraser, M. R. (2012). Surveying the extent of involvement in online academic dishonesty ( e-dishonesty ) related practices among university students and the rationale students provide: One university's experience. Computers in Human Behavior, 28, 849-860. http://dx.doi.org/10.1016/j.chb.2011.12.004

Eret, E., \& Ok, A. (2014). Internet plagiarism in higher education: Tendencies, triggering factors and reasons among teacher candidates. Assessment \& Evaluation in Higher Education, 39(8), 1002-1016. http://dx.doi.org/10.1080/02602938.2014.880776

Espasa, A., \& Meneses, J. (2010). Analyzing feedback processes in an online teaching and learning environment: An exploratory study. Higher Education, 59(3), 277-292. http://dx.doi.org/10.1007/s10734-009-9247-4

Faucher, D., Rn, S. C., \& Caves, S. (2009). Academic dishonesty: Innovative cheating techniques and the detection and prevention of them. Teaching and Learning in Nursing, 4(2), 37-41. http://dx.doi.org/10.1016/j.teln.2008.09.003

Gayton, J., \& McEwen, B. C. (2007). Effective online instructional and assessment strategies. The American Journal of Distance Education, 21(3), 117-132. http://dx.doi.org/10.1080/08923640701341653

Grijalva, T. C., Nowell, C., \& Kerkvliet, J. (2006). Academic honesty and online courses. College Student Journal, 40, 180-185.

Gulli, C. (2007). Cheating? Who us? Maclean's, 7, 41.

Gulli, C., Kohler, N., \& Patriquin, M. (2007). The great university cheating scandal. Maclean's, 120, 32-36.

Gullifer, J. M., \& Tyson, G. a. (2013). Who has read the policy on plagiarism? Unpacking students' understanding of plagiarism. Studies in Higher Education, (August), 1-17.

Hosny, M., \& Fatima, S. (2014). Attitude of students towards cheating and plagiarism: University case study. Journal of Applied Sciences, 14(8), 748-757. http://dx.doi.org/10.3923/jas.2014.748.757

Howe, N. S., \& Straus, W. (2003). Millennials go to college. Washington D.C: American Association of Collegiate Registrars and admissions officers.

Hughes, J. C., \& McCabe, D. (2006). Academic misconduct major problem in Canada, study finds. University of Guelph, Communications and Public Affairs. Retrieved from 
http://www.uoguelph.ca/mediarel/2006/09/academic_miscon.html

Jones, D. L. R. (2011). Academic dishonesty: Are more students cheating? Business Communication Quarterly, 74(2), 141-150. http://dx.doi.org/10.1177/1080569911404059

Keeler, L. C. (2006). Student satisfaction and types of interaction in distance education courses (Doctoral dissertation). Available from ProQuest Dissertations \& Theses database. (UMI No. 3233345).

Kennedy, K., Nowak, S., Raghuraman, R., Thomas, J., \& Davis, S. F. (2000). Academic dishonesty and distance learning: Student and faculty views. College Student Journal 34(2), 309-314.

King, C. G., Guette, R. W., Jr., \& Piotrowski, C. (2009, January). Online exams and cheating: An empirical analysis of business students' views. The Journal of Educators Online, 6(1), 1-11.

Kuo, Y.-C., Walker, A. E., Schroder, K. E. E., \& Belland, B. R. (2014). Interaction, Internet self-efficacy, and self-regulated learning as predictors of student satisfaction in online education courses. The Internet and Higher Education, 20, 35-50. http://dx.doi.org/10.1016/j.iheduc.2013.10.001

Magnus, J. R., Polterovich, V. M., Danilov, D. L., \& Savvateev, A. V. (2002). Tolerance of cheating: An analysis across countries. Journal of Economic Education, 33(2), 125-135. http://dx.doi.org/10.1080/00220480209596462

Malesic, J. (2006). How dumb do they think we are? Chronicle of Higher Education, 53,2-3.

McCabe, D. L. (1999). Academic dishonesty among high school students. Adolescence, 34(136), 681-687.

McCabe, D. L., Trevino, L. K., \& Butterfield, K. D. (2001). Cheating in academic institutions: A decade of research. Ethics and Behavior, 11(3), 219-232. http://dx.doi.org/10.1207/S15327019EB1103_2

McCabe, D. L., \& G. Pavela. (2004). Ten principles of academic integrity: How faculty can foster student honesty. Change, 36(3), 10-15. http://dx.doi.org/10.1080/00091380409605574

Michaels, J., \& Miethe, T. (1989). Applying theories of deviance to academic cheating. Social Science Quarterly, 70(4), 870-885.

Pavela, G. (1997). Applying the power of association on campus: A model code of academic integrity. Journal of College and University Law, 24(1), 97-118.

Paulhus, D. L., \& Vazire, S. (2007). The self-report method. In R.W. Robins, R.C. Fraley, \& R.F. Krueger (Eds.), Handbook of research methods in personality psychology (pp. 224-239). New York: Guiford Press.

Raines, D. A., Ricci, P., Brown, S. L., Eggenberger, T., Hindle, T., \& Schiff, M. (2011). Cheating in online courses: The student definition. Journal of Effective Teaching, 11(1), 80-89.

Robinson, V., \& Kuin, L. (1999). The explanation of practice. Why Chinese students copy assignments. International Journal of Qualitative Studies in Education, 12, 130-210. http://dx.doi.org/10.1080/095183999236259

Rowlatt, J. (2015, July 9). The vest that helps exam cheats. $B B C$. Retrieved from http://www.bbc.com/news/world-asia-india-33464732

Rowe, N. C. (2004). Cheating in online student assessment: Beyond plagiarism. Online Journal of Distance Learning Administration. Retrieved from http://www.westga.edu/ distance/ojdla/summer72/rowe72.html

Stuber-McEwen, D., Wiseley, P., \& Hoggatt, S. (2009). Point, click, and cheat: Frequency and type of academic dishonesty in the virtual classroom. Online Journal of Distance Learning Administration, 12(2).

Retrieved from http://www.westga.edu/ distance/ojdla/fall123/stuber123.html

Texas Tech University. (2010). McCabe academic integrity survey 2010. Lubbock: Office of Planning and Assessment. Retrieved from http://www.depts.ttu.edu/provost/qep/docs/McCabe_Academic_Integrity_Report_Cover.pdf

Thurmond, V. A., Wambach, K., Connors, H. R., \& Frey, B. B. (2002). Evaluation of student satisfaction: Determining the impact of a web-based environment by controlling for student characteristics. American Journal of Distance Education, 16(3), 169-190. http://dx.doi.org/10.1207/S15389286AJDE1603_4

Troop, D. (2007). You're never gonna believe this one. Chronicle of Higher Education, 53(4). Retrieved from http://www.chronicle.com/article/youre-never-gonna-believe/16333

Watson, G., \& Sottile, J. (2010). Cheating in the digital age: Do students cheat more in online courses? Online 
Alghamdi, E. A., Rajab, H., \& Rashid Shah, S.

Journal of Distance Learning Administration, 13(1). Retrieved from http://www.westga.edu/ distance/ojdla/spring131/watson131.html

Whitley, B. (1998). Factors associated with cheating among college students: A review. Research in Higher Education, 39(3), 235-273. http://dx.doi.org/10.1023/A:1018724900565

Young, S. (2006). Student views of effective online teaching in higher education. The American Journal of Distance Education, 20(2), 65-77. http://dx.doi.org/10.1207/s15389286ajde2002_2 